
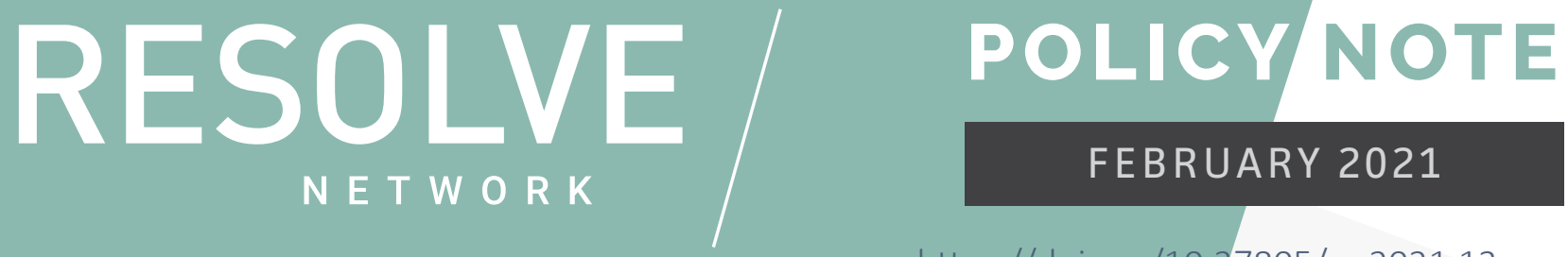

https://doi.org/10.37805/pn2021.13.remve

\title{
TACKLING WOMEN'S SUPPORT OF FAR-RIGHT EXTREMISM: EXPERIENCES FROM GERMANY
}

SERAN DE LEEDE

RACIALLY AND ETHNICALLY

MOTIVATED VIOLENT EXTREMISM

\section{${ }^{66}$ In recent years, both the number of women involved in far-right extremist groups and the number of women's groups in the scene has increased. ${ }^{99}$}

\section{FAST FACTS}

$\rightarrow$ Few projects aimed at young people and far-right extremism are concerned with gender beyond the archetype of violent skinhead males.

$\rightarrow$ Gender-stereotyping of women in far-right extremist groups can lead to blind spots in (criminal) investigations and have consequences for exit programs and prevention work.

$\rightarrow$ Research shows women and girls are strikingly underrepresented in disengagement, de-radicalization, and exit programs-an estimated three to ten percent of the participants in German exit programs are female.

\section{Context}

The rise in far-right extremist attacks-such as the mosque shooting in Christchurch, New Zealand, in March 2019 followed by two attacks in Germany: the synagogue shooting in Halle in October 2019 and the attack on two shisha bars in Hanau in February 2020-has sparked a renewed attention on far-right extremism. However, apart from the interest in Beate Zschäpe, the female member of the National Socialist Underground (NSU) currently serving a life sentence for her role in the crimes committed by the Neo-Nazi group, far-right extremism ${ }^{1}$ is mostly considered a field dominated by men. Misogynistic and patriarchal

1 While there is no universal definition of far-right extremism, it is generally understood as an anti-democratic, racist, and xenophobic ideology characterized by (politically inspired) violence, exclusionary nationalism, conspiracy theories, and authoritarianism. For more, see on a definition of right-wing extremism, see: Anders Javik Jupskås and Iris Beau Segers, "What is right-wing extremism?," 
views propagated by far-right groups intuitively lead to the presumption of women as passive followers subjugated to men rather than active or independent actors.

Persistent gendered assumptions about women and violence predominately depict women as non-violent and peaceful. Due to this gender blindness and simplistic frames used to understand the attraction of women toward far-right extremist groups, women tend to get overlooked as active participants, and their roles ignored or downplayed. This not only hinders the overall understanding of far-right extremist groups but also impedes the development of effective counterprograms that specifically address the experiences and paths of these women.

Germany has a long history of far-right extremism. Over the last thirty years, thanks to initiatives such as the Forschungsnetzwerk Frauen und Rechtsextremismus (Research Network on Women and Right-Wing Extremism) ${ }^{2}$ and the Amadeu Antonio Stiftung ${ }^{3}$, an increasing amount of research and monitoring specifically on far-right extremist women has been conducted in the country. Further contributing to the overall understanding of these women are initiatives like the Cultures Interactive project Women in Extremism and Prevention (WomEx) ${ }^{4}$, which collected and assessed practical experiences and research findings on the topic of women in (far-right) extremism from a two-year project from 2013 and 2014, and the ARUG-ZDB Project Frauen im Rechtsextremismus (Women in Right-Wing Extremism) ${ }^{5}$, which raises awareness concerning the far-right extremist, radical attitudes of women and girls in German society.

Their combined insights offer a wealth of information on women's roles and position in far-right extremist organizations, their motivations for joining such groups, and good practices in prevention and exit efforts aimed specifically at women and girls. Drawing from the experiences and insights of these German initiatives and from additional literature on the topic, this policy note explores the wide-ranging motivations of women joining far-right extremist groups and the different roles they can play in them. By including wider research to why women leave far-right extremist groups, the policy note offers lessons learned and recommendations that may be helpful in optimizing prevention and exit programs aimed at women in far-right extremist groups beyond the German context.

C-REX Center for Research on Extremism, August 31, 2020, https://www.sv.uio.no/c-rex/english/groups/compendium/whatis-right-wing-extremism.html.

2 A network of German scientists and journalists founded in 2000. The Research Network on Women and Right-Wing Extremism works on exchanging information on the topic of women, gender, and far-right extremism. Its 14 members have held lectures mostly in Germany but also in the international context and brought forth over 150 individual publications on the topic. See: http://frauen-und-rechtsextremismus.de/.

3 The Amadeu Antonio Foundation's goal is to reinforce a democratic civil society that promotes pluralism and human rights while opposing right-wing extremism, racism, and anti-Semitism. See: https://www.amadeu-antonio-stiftung.de/en/.

4 Result of the two-year ISEC funded project "Women/girls in violent extremism-WomEx" of the Berlin-based association Cultures Interactive. See: http://www.womex.org/en/about/the-womex-project/.

5 The Women in Right-Wing Extremism project of the Center for Democratic Education (ZDB), initiated by the Lower Saxony Ministry for Social Affairs, Health, and Equal Opportunities runs for three years with targeted educational work and the spread of right-wing extremism among women. See: https://www.arug-zdb.de/projekte-und-arbeitsbereiche/ abgeschlossene-projekte/frauen-im-rechtsextremismus/. 


\section{Relevance to policy and practice}

\section{Motivations and roles of women in far-right extremist groups in Germany}

In recent years, both the number of women involved in far-right extremist groups and the number of women's groups in the scene has increased. The assumption that women merely follow their male partners who introduce them to far-right extremist groups where they fall prey to (sexual) violence is persistent. Studies show that while a personal connection can be a way women (and men) enter far-right extremist groups, and while sexual repression of women is common in at least some far-right extremist groups, the reality of how and why women join is more complex. ${ }^{6}$

Women are attracted to far-right extremist groups by a multitude of factors. A predominant factor is hatred towards foreigners, which has been intensified by the European migration crisis and fueled by sensationalized stories, including those of sexual assaults and mistreatment of women by foreign men. ${ }^{7}$ Other motivating factors are centered around the desire to protect the Heimat (homeland) against foreign influences, capitalism, socialism, feminism, but also against moral decay including pornography and prostitution. ${ }^{8}$ While most women in far-right extremist organizations share the general views on racial purity and the need to protect the white race, they can hold very different viewpoints on women's role and position in this struggle. Some women focus predominantly on family issues, such as higher punishments for child-molesters and sex-offenders, ${ }^{9}$ where others oppose this focus on so-called "women's" or "family" issues and reject the portrayal of women as the "herds of the family". They advocate for women's rights and demand to be considered equal partners in life who contribute to the national Widerstand

6 Julia Ebner and Jacob Davey, "How Women Advance the Internationalization of the Far-Right," in Perspectives on the Future of Women, Gender, and Violent extremism, ed. Audrey Alexander (Washington, D.C.: George Washington University Program on Extremism, 2019) https://extremism.gwu.edu/sites/g/files/zaxdzs2191/f/Perspectives\%20on\%20the\%20Future\%20of\%20 Women\%2C\%20Gender\%20and\%20Violent\%20Extremism.pdf; Amadeu Antonio Stiftung, "Overlooked and Underrated: Women in Right-Wing Extremist Groups in Germany," Fachstelle Gender und Rechsextremismus, 2014, https://www.amadeuantonio-stiftung.de/w/files/pdfs/fachstelle/140407 overlooked-and-underrated.-german-women-in-right-wing-extremistgroups.pdf.

7 "Weiblich. Selbstbewusst. Rechts. Frauen im Rechtsextremismus," Zentrums Demokratische Bildung (ZDB), Niedersächischen Ministerium für Soziales, Gesundheit und Gleichstellung, Wolfsburg, 2015, https://www.arug-zdb.de/fileadmin/ user/Dokumente/Frauen rechts weiblich selbstbewusst.pdf; Renate Bitzan and Beate Hans, "Von rechten Kämpferinnen und braven Biederfrauen, Frauen und Rechtsextremismus, Ein Überblick," Nadir, 1998, https://www.nadir.org/nadir/archiv/ Feminismus/GenderKiller/gender 9.html; Joyce Marie Mushaben, "The rise of Femi-Nazis? Female participation in rightextremist movements in unified Germany," German Politics 5, no. 2 (1996), https://doi.org/10.1080/09644009608404440.

"Weiblich. Selbstbewusst. Rechts," Arug-ZDB; Mushaben, The rise of Femi-Nazis?;" Bitzan and Hans, "Von rechten Kämpferinnen und braven Biederfrauen." For more on far-right extremism and the concept of sexuality, see for example: Robert Claus and Fabian Virchow, "The Far Right's Ideological Constructions of 'Deviant' Male Sexualities," in Gender and Far Right politics in Europe, eds. Michaela Köttig, Renate Bitzan, Andrea Petö (London: Palgrave Macmillan, 2017): 305-320. https://doi. org/10.1007/978-3-319-43533-6.

9 Johanna Sigl, "Mädchen und Frauen in der extremen Rechten, Baustein zum Einsatz in der Politischen Bildung," Arbeitsstelle Rechtsextremismus und Gewalt-Zentrum Demokratische Bildung (ARUG-ZDB), December 19, 2019, https://www.arug-zdb. de/fileadmin/user/Dokumente/Frauen rechts Maedchen ARUG-ZDB.pdf 
(resistance, referring to the struggle to protect the nation) as full-fledged political actors. ${ }^{10}$ Some of them go as far as to openly challenge the patriarchal nature of the far right and the political silencing of women. ${ }^{11}$

Some women joining the far right do so looking for a purpose, a sense of belonging. Research shows that many women in far-right extremist groups have a troubled background, including experiences of substance abuse (either by themselves or relatives) and experiences of domestic and sexual violence. Often, these women look for intimacy to substitute the problematic or destructive family situation in which they were raised. ${ }^{12}$ Other, particularly younger, women and girls are attracted by the violent image of far-right extremist groups in their desire to feel empowered or to rebel against society. Some women feel disillusioned with feminism and frustrated with the present-day dating culture and are attracted to the propagation of traditional gender roles. ${ }^{13}$

The diversity in motivating factors and backgrounds is reflected in the far-right scene itself, which has become more heterogeneous over the years. Skingirls with the typical Renee hair style (short bangs with shaved heads) and Völkisch women (neo-Nazi women who adhere to the Nazi idealized family values and believe in a strict separation of the male and female sphere) with their traditional checkered skirts and long braids can still be found in the scene but no longer dominate it. Modern far-right women form a reflection of society and can be found in all its layers. ${ }^{14}$

With the diversification of the scene, the ways in which women can be involved has expanded. The stereotypical role as mothers raising white babies is still prominent, but some women, while recognizing the importance of motherhood, see a different role for themselves in the "struggle". Through assuming (local) political positions and careers in health, education, and in social sectors, and by volunteering in parent's organizations, kindergartens, youth centers, sports clubs, and nursing homes, they contribute to the spread and (social) acceptance of far-right ideas in mainstream society. They promote for example gender-related ideas that women should stay at home and care for their families and that gender-equality and homosexuality are unnatural, or speak out on migration-related topics on the grounds of women's safety. ${ }^{15}$ This way, women

10 Sigl, "Mädchen und Frauen in der extremen Rechten," ARUG-ZDB; "Weiblich. Selbstbewusst. Rechts," Arug-ZDB; Mushaben, "The rise of Femi-Nazis?"

11 Sigl, "Mädchen und Frauen in der extremen Rechten," ARUG-ZDB.

12 WomEx Final Conference October 1-2, 2014, WomEx, 2014: 35, https://www.cultures-interactive.de/tl files/projekte/ womex/Konferenzmappe Abschlusstagung 2014 en.pdf; Michaela Glaser, "Disengagement and Deradicalization Work with Girls and Young Women-Experiences from Germany," in Gender and Far Right politics in Europe, eds. Michaela Köttig, Renate Bitzan, Andrea Petö (London: Palgrave Macmillan, 2017): 342. https://doi.org/10.1007/978-3-319-43533-6.

"Weiblich. Selbstbewusst. Rechts," Arug-ZDB; Ebner and Davey, "How Women Advance the Internationalization of the FarRight," 35.

14 Sigl, "Mädchen und Frauen in der extremen Rechten," ARUG-ZDB; "Weiblich. Selbstbewusst. Rechts," Arug-ZDB.

15 "Weiblich. Selbstbewusst. Rechts," Arug-ZDB; Heike Radvan and Carmen Altmeyer, "Overlooked and underrated: women in right-wing extremist groups in Germany," Open Democracy, September 2, 2014, https://www.opendemocracy.net/en/ can-europe-make-it/overlooked-and-underrated-women-in-rightwing-extremi/; Annegret Wutschke, "Vom "Omakind" zur „Terrorbraut:“ Eine Analyse der Rolle der Frau im bundesdeutschen Rechtsterrorismus und der Konflikt mit rechtsextremistischen Weiblichkeitskonstruktionen," in Jahrbuch für Extremismus- und Terrorismusforschung ed. Armin Pfahl-Traughber (Brühl: Hochschule des Bundes für öffentliche Verwaltung, 2014): 233-258, https://www.hsbund.de/SharedDocs/Downloads/2 Zentralbereich/20 Referat W/50 Publikationen/20 Schriften Extremismus Terrorismusforschung/band 09. pdf? blob=publicationFile\&v=3; Glaser, "Disengagement and Deradicalization Work with Girls and Young Women," 337-338; 
provide far-right extremist groups with a cover of normality and, as women are often perceived less violent, construct a friendlier image of far-right extremist groups. ${ }^{16}$

In addition, while the percentage of women involved in far-right extremist violence is significantly lower than that of men (the percentage of women involved in registered far-right extremist crimes is estimated to range between 5-10 per cent) ${ }^{17}$ women can assume violent roles including arson and armed robberies and initiate or support violent attacks. ${ }^{18}$ Women have been known to lead (female) kameradschaften (comradeship) ${ }^{19}$ and to fight side by side their male counterparts, sometimes as so-called "racist fighters". ${ }^{20}$ Due to gender-stereotyping, women's violence is often overlooked or not taken seriously by the police and judiciary and youth workers. ${ }^{21}$

\section{German prevention and exit programs aimed at far-right extremist women and girls}

The gender-stereotyping of women as non-violent, in combination with the increased heterogenic character of the scene that makes it harder to identify far-right extremist women, poses serious challenges for exit work and de-radicalization programs. Different German programs and projects work specifically to raise awareness of the roles and relevance of far-right extremist women and/or develop programs to reach them. An overview of several of these organizations can be found on the WomEx-Cultures Interactive website. It includes the previously mentioned ARUG Frauen und Rechtsextremismus (Women in Right-Wing Extremism) Project that offers training for professionals and raises awareness about women in right-wing extremism. They have also worked with far-right extremist women in their exit programs. ${ }^{22}$

The NGO Cultures Interactive offers trainings for communities, youth workers, social workers, and nursery school staff dealing with far-right extremism, as well as gender-reflective workshops and

Silke Baer, Oliver Kossack, and Anika Posselius, "Gender Might Be the Key. Gender-Reflective Approaches and Guidelines in Prevention of and Intervention in Right-Wing Extremism in Europe," in Gender and Far Right politics in Europe, eds. Michaela Köttig, Renate Bitzan, Andrea Petö (London: Palgrave Macmillan, 2017): 362. https://doi.org/10.1007/978-3-319-43533-6.

Silke Baer and Anika Posselius, eds., "Gender-Reflective Prevention and Intervention Concepts for Dealing with RightWing Extremism, Group-Focused Enmity and Militant Religious Fundamentalism," Cultures Interactive and WomEx, 2015, https://www.cultures-interactive.de/tl files/publikationen/Flyer\%20Broschueren\%20Dokumentationen/2015 WomEx Cl Broschuere ENG.pdf; "Weiblich. Selbstbewusst. Rechts," Arug-ZDB.

17 Renate Bitzan, "Research on Gender and the Far Right in Germany Since 1990: Developments, Findings, and Future Prospects," in Gender and Far Right politics in Europe, eds. Michaela Köttig, Renate Bitzan, Andrea Petö (London: Palgrave Macmillan, 2017): 70. https://doi.org/10.1007/978-3-319-43533-6.

18 Glaser, "Disengagement and Deradicalization Work with Girls and Young Women;" "Weiblich. Selbstbewusst. Rechts," ArugZDB; Wutschke, "Vom „Omakind“ zur „Terrorbraut."”

19 Translates to comradeship and refers to self-proclaimed, often close-knit groups of far-right extremists who share the same world view.

20 "Weiblich. Selbstbewusst. Rechts," Arug-ZDB; Kathleen Blee, "Do white supremacist women adopt movement archetypes of mother, whore and fighter?," CREX-Center for Research on Extremism, December 15, 2020, https://www.sv.uio.no/c-rex/ english/news-and-events/right-now/2020/white-supremacist-women-movement-archetypes.html.

21 Baer and Posselius, "“Gender-Reflective Prevention and Intervention Concepts;" Baer et al., "Gender Might Be the Key," 362.

For more on their exit work, see: https://www.arug-zdb.de/rauszeitausstieg/fuer-aussteigerinnen/ 
youth culture programs. ${ }^{23}$ The Dissens Institute for Education and Research ${ }^{24}$ provides programs for youth to strengthen alternative role models for masculinity and femininity ${ }^{25}$ and Gangway ${ }^{26}$ runs projects for right-wing-oriented youth in Berlin, with a specific program for women and girls. This "Girl What" program works on the empowerment of women and girls and focuses on offering alternative ways of life, independence, sexual self-determination, and non-violence. ${ }^{27}$

Programs that offer anti-violence training specifically for women include the Institut für genderreflektierte Gewaltsprävention (Institute for Gender-reflective Violence Prevention, IfGG), that provides anti-violence trainings for boys and girls ages 11-18 who have exhibited aggressive behavior. ${ }^{28}$ In their experience, reasons for violent behavior are often similar for boys and girls: they try to free themselves from experiences of victimization, they want recognition and the opportunity to show power. However, the way boys and girls show and process violent behavior differ: women are often more subtle or indirect and their experiences as a victim of violence can differ significantly according to IfGG. In IfGG's experience, the program works best if offered to girls and boys separately. ${ }^{29}$ IMMA-Initiative for Munich Girls ${ }^{30}$ offers different forms of support for young women and girls in the Munich area, including training for girls who are prone to use violence. They work on changing violent behavior, improving communication skills, and increasing self-esteem, among others. ${ }^{31}$

Different exit programs working with far-right extremist women have also started to develop specific action plans for women and girls, including JUMP32 in Mecklenburg-West Pomerania state and the national Bundesarbeitgemeinschaft "Ausstieg zum Einstieg" (Federal Working Group "Exit to Enter," BAG Ausstieg). ${ }^{33}$ The experiences of these initiatives and programs together with the preceding discussion lead to the following recommendations for practitioners working with farright extremist women as well as for policymakers.

23 For more, see: “Examples of good practice/Projects" WomEx, http://www.womex.org/en/examples-of-good-practice-projects/

24 Dissens - Institute for Education and Research e.V. (registered association) is an education, consulting and research institute in Berlin. See: https://www.dissens.de/.

25 For more, see: "Dissens Institute for Education and Research e.V." WomEx, http://www.womex.org/en/ examples-of-good-practice-projects/dissens-institute-for-education-and-research-e-v/

26 Gangway works with young people and adults on the streets of Berlin. See: https://gangway.de/.

27 For more, see: “Jahresbericht Haushaltsjahr 2019," Gangway-Strassensozialarbeit In Berlin, 2019: 39-40, https://gangway. de/download/ueber-uns/gangway-jahresberichte/2019-Jahresbericht-Gangway.pdf.

28 Christiane Quadflieg and Laura Häußer, “Das TESYA ${ }^{\circledR}$-Deaf Antigewalttraining,” Manual, n.d. https://www.ifgg-berlin.de/ifgg/ wp-content/uploads/2018/04/ifgg TESYA Deaf Manual.pdf

29 Ibid, 10, 11, 24.

30 IMMA e.V.-Initiative for Munich Girls is a private youth welfare organization supporting girls and young women. See: https:// imma.de/.

31 Formore,see:"IMMAe.V.-InitiativeforMunichGirls," Womex,http://www.womex.org/en/examples-of-good-practice-projects/ imm-e-v-initiative-for-munich-girls/.

32 See: http://www.jump-mv.de/.

33 The nationwide umbrella association of civil society actors who provide exit and distancing assistance from extremely rightwing contexts. See: https://www.bag-ausstieg.de/. 


\section{Recommendations}

\section{Adopting a comprehensive gender perspective in projects aimed at (young) people involved in far-right extremism}

Few projects aimed at young people and far-right extremism are concerned with gender beyond the archetype of violent skinhead males. The Amadeu Antonio Stiftung warns that such programs often predominantly focus on young men, working on improving men's insecurity about their masculinity that far-right extremist groups have been known to prey on. ${ }^{34}$ That women can also support the hyper-patriarchal (toxic) gender roles and the "traditional values" embodied in far-right ideologies and that women can play an important role in such groups often remains unaddressed. The Expert Center on Gender and Right-Wing Extremism, ${ }^{35}$ founded by the Amadeu Antonio Stiftung, offers training for first-line practitioners to help promote the inclusion of gender in prevention and exit programs and encourages research on "right-wing femininity." ${ }^{36}$ This initiative could serve as an example for similar projects in other countries, facilitating gender mainstreaming in prevention and exit programs.

\section{Raising awareness among professionals}

Gender-stereotyping of women in far-right extremist groups can lead to blind spots in (criminal) investigations and have consequences for exit programs and prevention work. Raising awareness among professionals and offering training to those who may come across these women can help overcome these blind spots. In the case of police and judiciary services, women's violence is often overlooked or not taken seriously. Although the majority of far-right extremist violent acts are conducted by men, women also engage in these acts. The WomEx Project reports that in some cases extreme far-right groups use this bias by strategically deploying women for acts of violence, such as beatings of left-wing oriented girls. ${ }^{37}$ The project also reports that women have been known to incite men to violence, for example, by encouraging their male partner by making accusations along the lines of: "That foreigner came on to me, do something." ${ }^{8}$

Furthermore, women have been involved in verbal attacks, hate speech, and the spread of inciting texts online. WomEx emphasizes that while these acts may be more indirect compared to engaging in physical acts of violence, they are still expressions of violent behavior and should be recognized as such. ${ }^{39}$ Exit support practitioners involved in the WomEx project stated that they rarely come across female violent participants in the far-right scene because their deeds and activities often go unpunished. ${ }^{40}$ Raising awareness of the violent potential of women and of the different, indirect, ways women can incite violence can help in holding women accountable for their actions.

34 "Gender and the Far Right," Amadeu Antonio Stiftung, https://www.amadeu-antonio-stiftung.de/en/ gender-and-the-far-right/

Fore, see: "Expert Center on Gender and Right-Wing Extremism," Amadeu Antonio Stiftung, https://www.amadeu-antonio-stiftung.de/projekte/fachstelle-gender-und-rechtsextremismus/. 
Furthermore, women and girls involved in the far right can be more difficult to identify than their male counterparts. Michaela Glaser in her research on disengagement and deradicalization of far-right extremist young women and girls in the German context noticed that in schools, these girls often get overlooked in schools by their teachers. Their behavior is often less verbally or physically aggressive compared to that of their male counterparts and, as a consequence, is often not deemed problematic. ${ }^{41}$ Community and social workers who come across female supporters of the far-right similarly oftentimes overlook the behavior of girls and women. ${ }^{42}$ Greater support for teachers and community and social workers in terms of understanding and recognizing right-wing extremist symbols and codes (e.g. 88 , which stands for the $8^{\text {th }}$ letter in the alphabet referring to Heil Hitler), clothing brands (e.g. Erik \& Sons, Hermannsland, and Ansgar Aryan) or music choices may help in recognizing signs of far-right radicalization in girls and women. ${ }^{43}$ In that same vein, efforts to boost awareness for community members regarding resources available to address concerns about radical behavior can help in optimizing prevention work and responses. Trainings and workshops similar to those offered by Cultures Interactive ${ }^{44}$ and the Amadeu Antonio Stiftung Foundation ${ }^{45}$ focused on means by which to address and respond to women far-right extremists can serve as good examples for further programmatic efforts in this regard.

The experience of the WomEx Project suggests that awareness-raising among professionals working in welfare offices, child-protection services, family support programs, midwifery services, and women's shelters could be helpful in detecting possible involvement in far-right extremism among mothers (or parents) under their care. ${ }^{46}$ Since women in the far right have been known to suffer from domestic and sexual abuse, sensitizing staff in recognizing signs of women's involvement in far-right extremism and familiarizing them with existing initiatives that offer (exit) support could provide an opportunity to reach and adequately respond to those women looking for a way to exit from a far-right extremist group. According to WomEx, in several cases family support workers coming in contact with far-right extremist families indicated they felt unprepared for the situation. Training for professionals who encounter radicalized women can provide those professionals with the necessary tools to respond. ${ }^{47}$ Furthermore, health care institutions have been known to be the target of infiltration strategies of right-wing extremist organizations-awareness among health professionals working in these institutions may help prevent such attempts. ${ }^{48}$

\section{Developing gender-specific tools that reach far-right extremist women and girls (including online)}

Research shows women and girls are strikingly underrepresented in disengagement, deradicalization, and exit programs - an estimated three to ten percent of the participants in German exit programs are female. ${ }^{49}$ According to Michaela Glaser, this can be explained in part by the

41 Glaser, "Disengagement and Deradicalization Work with Girls and Young Women," 343.

42 Baer et al., "Gender Might Be the Key," 361-362.

43 "Weiblich. Selbstbewusst. Rechts," Arug-ZDB; Baer and Posselius, "Gender-Reflective Prevention and Intervention Concepts."

44 See: http://www.womex.org/en/about/the-womex-project/.

45 See: https://www.amadeu-antonio-stiftung.de/en/.

46 WomEx Final Conference October 1-2, 2014, WomEx, 2014: 17.

47 Ibid, 18.

48 Ibid, 18; Radvan and Altmeyer, "Overlooked and underrated."

49

WomEx Final Conference October 1-2, 2014, WomEx, 2014: 32. 
strategies used by professionals to establish contact with their "target group". As Glaser points out, professionals often reach out to clients through so-called street work ${ }^{50}$ and in (self-run) youth clubs, but youth clubs are often poorly attended by girls, making it more difficult for outreach workers to initiate contact with these women. ${ }^{51}$ Glaser also notes that far-right extremists can also be referred to exit support programs through the criminal justice system and its related institutions, often initiated by the police, judges, and probation officers. ${ }^{52}$ However, since women are rarely arrested or convicted for far-right extremism-related offences, women are less likely to get referred to exit support programs through those channels. ${ }^{53}$

Practitioners in the WomEx project indicated they found it easier to gain access to women in farright extremist groups and to discuss gender-related issues through online platforms. ${ }^{54}$ Social media might be an effective way to reach far-right extremist women and girls. A study by the Institute for Strategic Dialogue (ISD), for example, found that online interventions have the potential to reach more individuals than those that occur offline and could be used to direct people to offline support services. ${ }^{55}$ Radicalized individuals actively seek support from intervention providers online. Therefore, increasing the visibility of intervention services through online promotion could help reach those considering leaving (far-right) extremist groups. ${ }^{56}$ Investing in online interventions and the online promotion of offline support services could reach far-right extremist women, especially those considering leaving but who are unsure where to turn to.

\section{Learning from global efforts: Recognizing gender-specific factors for the exit process of women}

While there are many lessons to be drawn from the German context, important findings about the exit process of women from far-right extremism exist around the world. Research findings from the United States (U.S.), for example, suggest that exiting can, in some cases, be more difficult for women. Women's exit is often seen as a double betrayal of the cause, especially when there are children related to a man belonging to the far-right, as these children may be seen as a possession of the movement. ${ }^{57}$ Women involved in far-right extremist groups often suffered domestic and sexual abuse and humiliation, either in their childhood, at the hands of their right-wing extremist counterparts, or both. ${ }^{58}$ In far-right extremist groups in the U.S., for example, women have been reportedly forced to work as sex-workers to financially support their husbands or male partners

50 According to Glaser, Streetwork projects work in public spaces with young people who cannot be reached by other youth work or social work programs. These young people are regarded at risk of becoming far-right extremists. They display rightwing extremist symbols, listen to far-right extremist music, and may act violently towards foreigners and minorities. See: Glaser, “Disengagement and Deradicalization Work with Girls and Young Women," 339.

51 Glaser, "Disengagement and Deradicalization Work with Girls and Young Women," 342.

52 Ibid.

53 Ibid.

54 WomEx Final Conference October 1-2, 2014, WomEx, 2014: 13.

55 Jacob Davey, Henry Tuck, Amarnath Amarasingam, "An imprecise science: assessing interventions for the prevention, disengagement and de-radicalisation of left- and right-wing extremists," Institute for Strategic Dialogue, 2019, https://www. isdglobal.org/wp-content/uploads/2019/11/An-imprecise-science-1.pdf.

56 Ibid

57 WomEx Final Conference October 1-2, 2014, WomEx, 2014.

58 WomEx Final Conference October 1-2, 2014, WomEx, 2014; Glaser, "Disengagement and Deradicalization Work with Girls and Young Women;" "Weiblich. Selbstbewusst. Rechts," Arug-ZDB. 
and the movement itself. ${ }^{59}$ Such traumatic experiences in combination with an abusive partner can provide additional challenges to the already complicated exit process. ${ }^{60}$ Professionals working with these women may benefit from a wider perspective of tools and tactics to adequately respond to these issues.

According to recent studies in the U.S., women can become disillusioned with the group when they feel betrayed (by other women), especially women who joined the far right in search for belonging and a welcoming family to substitute their troubled relationships in the past. Some women leave when violence becomes a threat to their children. ${ }^{61}$ For some women the emphasis on women's traditional role as mothers was disappointing and a reason to turn away, together with feelings of frustration over the lack of personal agency, the portrayal of women as sexual prey for men, and the mistreatment of women in the movement. Among other relevant factors for wanting to leave the movement, women cited feeling overburdened with the emotional, social, physical, and economic costs of being in an extremist group and wanting to provide a more socially and economically stable life for themselves and their children. ${ }^{62}$

Wanting to leave a far-right extremist movement does not necessarily lead to actually pulling out of the movement. In several cases, women in U.S. far-right extremist groups had been disillusioned with either the group or the ideology for a long time before finally turning away from the scene. Studies on women in these far-right extremist groups show there are different reasons that keep them from leaving. They may fear reprisal from group members against them and their children. Some fear criminal prosecution for their involvement in the movement or stigmatization by society. Especially for those who have been involved in the movement for a long time, being a member has provided a sense of belonging and identity. Pulling out of the movement means losing this sense of belonging and identity, as well as the long-time friendships and protection against external enemies and opponents that came with it. ${ }^{63}$ In some cases, women in the U.S. have been coerced or pressured into staying. ${ }^{64}$ Research suggests that women in the U.S. mostly stay in far-right movements because they cannot imagine how to get out safely-opportunities to leave, such as a safe social connection outside the group, the prospect of a job, or the rebuilding of broken family relations, are significant factors for why women turn away in the end.$^{65}$ Interestingly, studies on the US point out that this factor is seldom mentioned in studies on far-right extremist

59 Blee, "Do white supremacist women adopt movement archetypes."

60 WomEx Final Conference October 1-2, 2014, WomEx, 2014.

61 A woman in a study said she pulled out of the white supremacist movement out of fear that her daughter was becoming vulnerable to physical and sexual abuse from men in the group. See: Mehr Latif, Kathleen Blee, Matthew Demichele, Pete Simi, and Shayna Alexander, "Why White Supremacist Women Become Disillusioned, and Why They Leave," The Sociological Quarterly 61, no. 3, (2020): 378. https://doi.org/10.1080/00380253.2019.1625733.

62 Blee, "Do white supremacist women adopt movement archetypes."; Kathleen Blee, Pete Simi, Mehr Latif, Matthew Demichele, "Why do women leave the Far-Right?," C-REX-Center for Research on Extremism, July 9, 2018, https://www.sv.uio. no/c-rex/english/news-and-events/right-now/2018/why-do-women-leave-the-far-right.html.

63 Latif et al., "Why White Supremacist Women Become Disillusioned, and Why They Leave;" Blee et al., "Why do women leave the Far-Right?."

64 One woman explained that her husband said she would never make it on her own, that she could not support herself, and that he would fight her over the kids. See: Latif et al., "Why White Supremacist Women Become Disillusioned, and Why They Leave," 379.

65 Blee et al., "Why do women leave the Far-Right?;" Latif et al., "Why White Supremacist Women Become Disillusioned, and Why They Leave." 
men, pointing to a window of opportunity for women-specific exit programs. ${ }^{66}$

\section{Conclusion}

Far-right extremism is mostly considered to be dominated by men; women are assumed passive followers rather than active participants. This policy note demonstrates that women can have different motivations for joining far-right extremist groups, including racist and xenophobic views, a desire to protect the white race and the nation against foreign influences, anti-feminist views, and attraction to traditional gender roles. Over the years, the far-right extremist scene has become more diverse, attracting more women from different layers of society. Women's roles in far-right extremist movements have also expanded. While raising their families by far-right extremist ideology is still a key role for women, women also engage in violence and have started to assume (local) political positions and careers in health, education, and social sectors. Through these positions, and by volunteering in youth centres, sports clubs, and nursing homes, women help spread far-right extremist ideas in society and advance the social acceptance of those ideas. As such, women's participation in far-right extremist movements should not be ignored.

In recent years, different initiatives in Germany have focused on women in far-right extremism, bringing together the insights of practitioners and researchers from different fields. They work to raise awareness of the roles and relevance of far-right extremist women and to develop prevention and exit strategies specifically aimed at women. The experiences of these initiatives and the lessons they can lend to other efforts to address women engaged in far-right extremist movements are valuable resources in expanding similar efforts around the globe. 


\section{Suggested further reading}

\section{On women in far-right extremist groups}

Dauber, Andrea S. "Not all Nazis are men: Women's underestimated potential for violence in German Neo-Nazism. Continuation of the past or novel phenomenon?." In Gendered Perspectives on Conflict and Violence: Part B (Advances in Gender Research, Vol. 18B) Emerald Group Publishing Limited, 2014: 171-194. https://doi.org/10.1108/S1529-21262014000018B011.

Ebner, Julia, and Jacob Davey. "How Women Advance the Internationalization of the Far-Right." In Perspectives on the Future of Women, Gender and Violent Extremism, edited by Audrey Alexander. Washington, D.C.: George Washington University Program on Extremism, 2019. https://extremism.gwu. edu/sites/g/files/zaxdzs2191/f/Perspectives\%20on\%20the\%20Future\%20of\%20Women\%2C\%20 Gender\%20and\%20Violent\%20Extremism.pdf.

Mushaben, Joyce Marie. "The rise of Femi-Nazis? Female participation in right-extremist movements in unified Germany," German Politics 5, no. 2 (1996). https://doi.org/10.1080/09644009608404440.

Röpke, Andrea, and Andreas Speit. Mädelsache!, Frauen in der Neonazi-Szene. Christoph Links Verlag: Berlin, 2011.

Köttig, Michaela, Renate Bitzan, Andrea Petö. Gender and Far Right politics in Europe. London: Palgrave Macmillan, 2017.

On prevent and exit- programs and women in far-right extremist groups

Baer, Silke, Oliver Kossack, and Anika Posselius. "Gender Might Be the Key. Gender-Reflective Approaches and Guidelines in Prevention of and Intervention in Right-Wing Extremism in Europe." In Gender and Far Right politics in Europe, edited by Michaela Köttig, Renate Bitzan, Andrea Petö, 351-369. London: Palgrave Macmillan, 2017. https://doi.org/10.1007/978-3-319-43533-6.

Glaser, Michaela. "Disengagement and Deradicalization Work with Girls and Young Women-Experiences from Germany." In Gender and Far Right politics in Europe, edited by Michaela Köttig, Renate Bitzan, Andrea Petö, 337-350. London: Palgrave Macmillan, 2017. https://doi.org/10.1007/978-3-319-43533-6.

Latif, Mehr, Kathleen Blee, Matthew Demichele, Pete Simi, and Shayna Alexander. "Why White Supremacist Women Become Disillusioned, and Why They Leave." The Sociological Quaterly 61, no. 3, (2020): 378. https://doi.org/10.1080/00380253.2019.1625733.

WomEx Final Conference October 1-2, 2014. WomEx, 2014. https://www.cultures-interactive.de/tl files/ projekte/womex/Konferenzmappe Abschlusstagung 2014 en.pdf.

Women/girls in violent extremism-WomEx. http://www.womex.org/en. 


\section{Sources}

Amadeu Antonio Stiftung. "Overlooked and Underrated: Women in Right-Wing Extremist Groups in Germany." Fachstelle Gender und Rechsextremismus, 2014. https://www.amadeu-antonio-stiftung.de/w/ files/pdfs/fachstelle/140407 overlooked-and-underrated.-german-women-in-right-wing-extremistgroups.pdf.

Baer, Silke, Oliver Kossack, and Anika Posselius. "Gender Might Be the Key. Gender-Reflective Approaches and Guidelines in Prevention of and Intervention in Right-Wing Extremism in Europe." In Gender and Far Right politics in Europe, edited by Michaela Köttig, Renate Bitzan, Andrea Petö, 351-369. London: Palgrave Macmillan, 2017. https://doi.org/10.1007/978-3-319-43533-6.

Baer, Silke, and Anika Posselius, eds. "Gender-Reflective Prevention and Intervention Concepts for Dealing with Right-Wing Extremism, Group-Focused Enmity and Militant Religious Fundamentalism." Cultures Interactive and WomEx, 2015. https://www.cultures-interactive.de/tl files/publikationen/Flyer\%20 Broschueren\%20Dokumentationen/2015 WomEx Cl Broschuere ENG.pdf.

Bitzan, Renate, and Beate Hans. "Von rechten Kämpferinnen und braven Biederfrauen, Frauen und Rechtsextremismus, Ein Überblick." Nadir, 1998. https://www.nadir.org/nadir/archiv/Feminismus/GenderKiller/gender 9.html.

Bitzan, Renate. "Research on Gender and the Far Right in Germany Since 1990: Developments, Findings, and Future Prospects." In Gender and Far Right politics in Europe, edited by Michaela Köttig, Renate Bitzan, Andrea Petö, 65-79. London: Palgrave Macmillan, 2017. https://doi.org/10.1007/978-3-319-43533-6.

Blee, Kathleen. "Do white supremacist women adopt movement archetypes of mother, whore and fighter?." CREX-Center for Research on Extremism, December 15, 2020. https://www.sv.uio.no/c-rex/english/ news-and-events/right-now/2020/white-supremacist-women-movement-archetypes.html.

Blee, Kathleen, Pete Simi, Mehr Latif, Matthew Demichele. "Why do women leave the Far-Right?." C-REXCenter for Research on Extremism, July 9, 2018. https://www.sv.uio.no/c-rex/english/news-and-events/ right-now/2018/why-do-women-leave-the-far-right.html.

Claus, Robert, and Fabian Virchow. "The Far Right's Ideological Constructions of 'Deviant' Male Sexualities." In Gender and Far Right politics in Europe, edited by Michaela Köttig, Renate Bitzan, Andrea Petö, 305-320. London: Palgrave Macmillan, 2017. https://doi.org/10.1007/978-3-319-43533-6.

Davey, Jacob, Henry Tuck, Amarnath Amarasingam. "An imprecise science: assessing interventions for the prevention, disengagement and de-radicalisation of left- and right-wing extremists." Institute for Strategic Dialogue, 2019. https://www.isdglobal.org/wp-content/uploads/2019/11/An-imprecise-science-1.pdf.

Ebner, Julia, and Jacob Davey. "How Women Advance the Internationalization of the Far-Right." In Perspectives on the Future of Women, Gender and Violent Extremism, edited by Audrey Alexander. Washington, D.C.: George Washington University Program on Extremism, 2019. https://extremism.gwu. edu/sites/g/files/zaxdzs2191/f/Perspectives\%20on\%20the\%20Future\%20of\%20Women\%2C\%20 Gender\%20and\%20Violent\%20Extremism.pdf.

"Gender and the Far Right," Amadeu Antonio Stiftung, https://www.amadeu-antonio-stiftung.de/en/ gender-and-the-far-right/. 
Glaser, Michaela. "Disengagement and Deradicalization Work with Girls and Young Women-Experiences from Germany." In Gender and Far Right politics in Europe, edited by Michaela Köttig, Renate Bitzan, Andrea Petö, 337-350. London: Palgrave Macmillan, 2017. https://doi.org/10.1007/978-3-319-43533-6.

Jupskås, Anders Javik, and Iris Beau Segers. "What is right-wing extremism?." C-REX Center for Research on Extremism, August 31, 2020. https://www.sv.uio.no/c-rex/english/groups/compendium/what-is-right-wing-extremism.html.

Latif, Mehr, Kathleen Blee, Matthew Demichele, Pete Simi, and Shayna Alexander. "Why White Supremacist Women Become Disillusioned, and Why They Leave." The Sociological Quaterly 61, no. 3, (2020): 378. https://doi.org/10.10 $\underline{80 / 00380253.2019 .1625733 .}$

Mushaben, Joyce Marie. "The rise of Femi-Nazis? Female participation in right-extremist movements in unified Germany," German Politics 5, no. 2 (1996). https://doi.org/10.1080/09644009608404440.

Quadflieg, Christiane, and Laura Häußer. "Das TESYA ${ }^{\circledR}$-Deaf Antigewalttraining." Manual, n.d. https://www.ifgg-berlin.de/ ifgg/wp-content/uploads/2018/04/ifgg TESYA Deaf Manual.pdf.

Radvan, Heike, and Carmen Altmeyer. "Overlooked and underrated: women in right-wing extremist groups in Germany." Open Democracy, September 2, 2014. https://www.opendemocracy.net/en/can-europe-make-it/ overlooked-and-underrated-women-in-rightwing-extremi/.

Sigl, Johanna. "Mädchen und Frauen in der extremen Rechten, Baustein zum Einsatz in der Politischen Bildung." Arbeitsstelle Rechtsextremismus und Gewalt-Zentrum Demokratische Bildung (ARUG-ZDB), December 19, 2019. https:// www.arug-zdb.de/fileadmin/user/Dokumente/Frauen rechts Maedchen ARUG-ZDB.pdf.

"Weiblich. Selbstbewusst. Rechts. Frauen im Rechtsextremismus." Zentrums Demokratische Bildung (ZDB), Niedersächischen Ministerium für Soziales, Gesundheit und Gleichstellung, Wolfsburg, 2015. https://www.arug-zdb.de/fileadmin/user/Dokumente/Frauen rechts weiblich selbstbewusst.pdf.

WomEx Final Conference October 1-2, 2014. WomEx, 2014. https://www.cultures-interactive.de/tl files/projekte/ womex/Konferenzmappe Abschlusstagung 2014 en.pdf.

Wutschke, Annegret. “Vom „Omakind“ zur „Terrorbraut:“ Eine Analyse der Rolle der Frau im bundesdeutschen Rechtsterrorismus und der Konflikt mit rechtsextremistischen Weiblichkeitskonstruktionen." In Jahrbuch für Extremismusund Terrorismusforschung edited by Armin Pfahl-Traughber, 233-258. Brühl: Hochschule des Bundes für öffentliche Verwaltung, 2014. https://www.hsbund.de/SharedDocs/Downloads/2 Zentralbereich/20 Referat W/50 Publikationen/20 Schriften Extremismus Terrorismusforschung/band 09.pdf? blob=publicationFile\&v=3. 



\section{About the Note}

Author: Seran de Leede

Seran de Leede works on the topic of women, gender and political violence as an independent researcher and as an associate fellow for the International Centre for Counter-Terrorism (ICCT), the Hague. Her research interests include the involvement of women in violent extremist groups and the relevance of gender in understanding and countering/preventing violent extremism. In her recent publications, she explored the role of women in De Rode Jeugd (The Red Youth, a violent radical Left group active in the Netherlands in the 1970s); the position of Afghan women towards the Taliban; the relevance of adopting a gender perspective in efforts aimed to counter/ prevent violent extremism; the motivations and roles of Western women supporting the Islamic State (ISIS) and the roles (and relevance) of women in jihadist groups. Most recently, she coauthored a toolkit for professionals working with Islamist radicalized women and girls.

The views expressed in this publication are those of the authors. They do not necessarily reflect the views of the RESOLVE Network, the U.S. Institute of Peace, or any entity of the U.S. government.

\section{RESOLVE NETWORK}

better research.informed practice.improved policy on violent extremism.

www.resolvenet.org

y $f$ in 